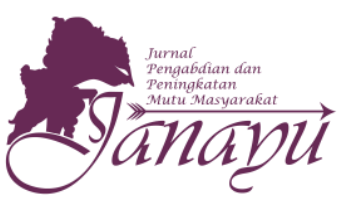

Website:

ejournal.umm.ac.id/index.php/janayu

Afiliasi:

${ }^{1}$ Fakultas Ekonomi dan Bisnis, Universitas Muhammadiyah Malang, Malang, Jawa Timur, Indonesia

*Correspondence:

noviprimita@umm.ac.id

DOI: $10.22219 /$ janayu.v1i2.12439

Sitasi:

Sari, N.P., \& Fuddin, M.K. (2020). Penyusunan Laporan Keuangan Berbasis Teknologi Informasi Paud Cita Sakinah. Jurnal Pengabdian dan Peningkatan Mutu Masyarakat, 1(2), $126-135$.

Proses Artikel

Diajukan:

7 Juni 2020

Direviu:

8 Juni 2020

Direvisi:

19 Juli 2020

Diterima:

22 Juli 2020

Diterbitkan:

29 Juli 2020

Alamat Kantor:

Jurusan Akuntansi Universitas

Muhammadiyah Malang

Gedung Kuliah Bersama 2

Lantai 3.

Jalan Raya Tlogomas 246,

Malang, Jawa Timur,

Indonesia

P-ISSN: 2721-0421

E-ISSN: 2721-0340
Tipe Artikel: Paper Pengabdian

\section{Penyusunan Laporan Keuangan Berbasis Teknologi Informasi Paud Cita Sakinah}

\author{
Novi Primita Sari ${ }^{{ }^{*}}$, M. Khoirul Fuddin ${ }^{1}$
}

\section{ABSTRACT}

The existence of the family as a place to provide education and first knowledge for children is very important. Today because of the times, many parents choose to work, especially a mother, so that their children must be cared for and entrusted to their relatives and others and there are even parents who choose to provide early education to children, namely by providing education since early through playing school or what we often hear with PAUD istila. PAUD Cita Sakinah under the auspices of PCM Karangploso Malang Regency. Where in the PCM's vision and mission one of them is to do the greatness of honor from an early age, form the character of children's independence and make children to always behave and be based on principles based on Islam and Kemuhammadiyahan. Since the founding of Cita Sakinah PAUD, there are problems faced, which are related to financial management, which is still very traditional by doing manual bookkeeping. So that through this service and assistance program it is expected that PAUD managers will be able to prepare a systematic financial report based on technology.

KEYWORDS: Accompaniment, Financial System; Financial Reports; PAUD

\section{ABSTRAK}

Keberadaan keluarga sebagai tempat pemberi Pendidikan dan pengetahuan pertama bagi anak adalah hal yang sangat penting. Dewasa ini karena perkembangan zaman banyak sekali orangtua yang memilih bekerja khususnya seorang ibu, sehingga anak-anak mereka terpaksa diasuh dan dititipkan kepada sanak saudara keluarga maupun orang lain bahkan ada juga orangtua yang memilih untuk memberikan Pendidikan dini kepada anak, yaitu dengan cara memberikan Pendidikan sejak dini melalu sekolah bermain atau yang sering kita dengar dengan istila PAUD. PAUD Cita Sakinah di bawah naungan PCM Karangploso Kabupaten Malang. Dimana dalam visi misi PCM salah satunya adalah untuk melakukan syiar kemuhammadiyahan dari sejak dini, membentuk karakter kemandirian anak dan menjadikan anak agar senantiasa berperilaku serta berprinsip berlandaskan Islam dan Kemuhammadiyahan. Dari sejak berdirinya PAUD Cita Sakinah ini terdapat permasalahan yang dihadapi yaitu terkait pengelolaan keuangannya masih sangat tradisonal dengan cara melakukan pembukuan manual. Sehingga melalui program pengabdian dan pendampingan ini diharapkan pengelola PAUD dapat Menyusun laporan keuangan secara sistematis berbasis teknologi.

KATA KUNCI: Laporan Keuangan; PAUD; Pendampingan; Sistem Keuangan 


\section{PENDAHULUAN}

Keberadaan keluarga sebagai tempat pemberi Pendidikan pertama bagi anak adalah hal yang sangat penting, mengingats egala sesuatu untuk pertama kali yang dipelajari oleh anak adalah melalui peran keluarga khususnya orangtua. Pentingnya Pendidikan dini pada anak telah menajdi sebuah perhatian banyak kalangan termasuk pemerintah. Ada anggapan bahwa Pendidikan baru bisa dimulai setelah usia sekolah dasar ternyata tidak benar, bahkan Pendidikan yang dimulai dari usia taman kanak-kanak pun sudah terlambat (Purnomo, 2013). Di masa lampau, wanita masih sangat terikat dengan nilai-nilai tradisional yang sedemikian rupa mengakar ditengah-tengah masyarakat, yaitu seorang wanita hanya menjadi ibu rumah tangga dan melayani suami. Bila ada wanita yang berkarir di luar rumah, wanita dianggap telah melanggar tradisi sehingga mereka dikucilkan dalam pergaulan masyarakat dan lingkungannya. Denga demikian wanita kurang mendapat kesempatan untuk mengembangkan diri di tengah - tengah masyarakat. Sejalan dengan perkembangan zaman, kaum wanita dewasa ini khususnya wanita yang tinggal di kota - kota besar maupun di pedesaan cenderung untuk berperan ganda bahkan ada yang multi fungsional karena wanita telah memperoleh kesempatan yang seluas - luasnya untuk mengembangkan diri sehingga jabatan dan pekerjaan penting di dalam masyarakat tidak lagi dimonopoli oleh kaum lakilaki (Nurmila, 2017).

Dewasa ini karena perkembangan zaman, banyak sekali orang tua yang memilih bekerja khususnya seorang ibu, sehingga anak terpaksa diasuh dan dititipkan kepada sanak keluarga maupun orang lain. Karena perkembangan ini maka banyak bermunculan tempat - tempat penitipan anak dengan tambahan pola pendidikan yang memiliki kurikulum serta fasilitas dan harga yang beragam. Salah satunya adalah Pendidikan Anak Usia Dini (PAUD) Cita Sakinah dibawah naungan PDM Kabupaten Malang. PAUD Cita Sakinah ini dalam perkembangannya mengalami progres yang cukup menjanjikan, dimana banyak para ibu ibu terutama para ibu yang memiliki pekerjaan yang cukup padat mulai mempercayakan penitipan anakanya kepada PAUD Cita Sakinah. Dengan adanya fenomena tersebut tentu saja PAUD Cita Sakinah harus segera berbenah dalam segala aspek untuk bertransformasi menjadi sebagai badan usaha yang profesional dalam bekerja dan memberikan layanan prima bagi para ibu - ibu yang sudah mempercayakan putra - putrinya untuk mendapatkan pendidikan yang sesuai. Salah satu cara untuk membuat PAUD Cita Sakinah jauh lebih profesional dalam bekerja adalah dengan membantu menyusun membuat laporan keuangan sederhana untuk mengatur kondisi arus kas yang terdapat pada PAUD Cita Sakinah.

Laporan keuangan sangat berpengaruh terhadap pendapatan suatu perusahaan, dimana laporan keuangan harus dilaporkan setiap periode akuntansi, untuk mengetahui berapa besar pendapatan dan pengeluaran, untuk digunakan sebagai informasi bagi pihak yang membutuhkannya (Rahmayuni, 2017). Pendampingan pengelolaan penyusunan laporan keuangan ini dirasakan cukup penting mengingat PAUD Cita Sakinah akan bertransformasi menjadi Lembaga Pendidikan yang professional sehingga dalam pengelolaannya perlu adanya keterbukaan, akuntabilitas dan juga pertanggungjawaban secara terperinci terhadap sumber dana dan penggunaan dana-dana. Selain itu penyusunan laporan keuangan yang berbasis teknologi informasi (komputer) diharapkan dimasa depan laporan keuangan PAUD Cita Sakinah dapat diakses secara mudah dan baik oleh para pengurus dan oleh orang tua siswa didik mengenai berbagai macam pembayaran yang telah dilakukan dan dana tersebut telah digunakan untuk kegiatan apa saja yang mampu mendukung tumbuh kembang siswa didik. Kegiatan tersebut bisa jadi berupa, infak setiap hari jumat, berbagi 
sedekah di minggu ceria dengan tema-tema yang telah dipilih oleh pengurus PAUD, dan rihlah Bersama para orangtua siswa didik.

\section{METODE}

Memasuki wilayah kompleks Griya Pernata Alam (GPA) Ngijo Kecamatan Karangploso Kab. Malang hal yang pertama kali disuguhkan adalah jalanan berbukit yang menanjak dan dikelilingi oleh begitu banyak dan bermacam-macam perumahan. Bagi warga baru seperti saya didaerah karangploso cukup mengalami kesulitan untuk menghafal dan mencari lokasi. Sampai akhirnya saya membuka website Pimpinan Cabang Muhammadiyah (PDM) Kabupaten Malang, dan menemukan salah satu AUM meskipun tidak dijelaskan secara detail dalam web karena hanya tertera alamat dan nama AUM. Lokasi AUM Lokasi pengadian masyarakat ini dilaksanakan pada amal usaha Muhammadiyah yang dijadikan sebagai lokasi pengabdian berada dalam satu kompleks Masjid KH. Ahmad Dahlan, terdapat tiga AUM yang sangat aktif disana, yaitu tempat penitipan anak (TPA) Cita Sakinah, TPQ dan pendidikan usia dini (PAUD) yang baru saja dibuka tahun ajaran baru ini. Tujuan dari pendirian berbagai AUM ini tertutama PAUD Cita Sakinah adalah :

1. Ingin melakukan syiar Kemuhammadiyahan yang dilakukan sejak dini.

2. Membentuk karakter anak-anak dari kecil agar mulai mengenal bersosialisasi secara Islami, mengenal masjid dan lingkungan masjid.

3. Menjadikan anak memiliki prinsip dan tingkah laku berlandaskan Islam dan Kemuhammadiyahan.

Program pengabdian ini juga mengacu dari berbagai program pengabdian yang memiliki permasalahan serupa, tujuannya adalah untuk acuan atau sebagai dasar program pengabdian masyarakat yang dilakukan melalui pemberian pelatihan pembuatan laporan keuangan. Metode program pengabdian ini dilakukan dengan cara mengumpulkan data dari calon responden atau mitra yang akan diberikan pelatihan pembuatan pelaporan keuangan yaitu para pegawai atau pengurus pendidikan anak usia dini (PAUD) Cita Sakinah, kemudian Langkah selanjutnya menyusun, dan mendeskripsikan sehingga diperoleh hasil berupa gambaran yang jelas tentang objek yang akan dilakukan program pengabdian masyarakat (Akhsanul Haq, 2015).

Kegiatan pengabdian ini juga dilakukan melalui pendampingan dan pelatihan penyusunan laporan keuangan secara bertahan, yaitu dapat dilihat pada bagan dibawah ini :

Bagan 1.

Metode

Kegiatan Pengabdian
Penelusuran awal permasalahan mitra terkait penyusunan laporan keuangan yang dilakukan oleh mitra selama ini

Mengidentifikasi setiap transaksi keuangan agar dapat dimasukkan kedalam system computer (excel)

Mitra memiliki laporan keuangan yang sistematis dan juga mitra mampu Menyusun serta menyajikan laporan keuangan yang kredibel dan transparan.
Janayu 1.2 
Materi yang diberikan dalam program pengabdian terhadap PAUD Cita Sakinah ini diantara lain terkait :

1. Pengertian dan manfaat laporan keuangan bagi PAUD Cita Sakinah.

2. Menyusun laporan keuangan mulai dari hal perncanaan, pengendalian hingga tahapan terakhir yaitu evaluasi laporan keuangan yang telah disusun dan dibuat.

3. Tahapan dalam penyusunan laporan keuangan berbasis teknologi informasi (computer excel),

Dari materi yang diberikan tersebut diharapkan tercapainya tujuan dari program pengabdian ini. Informasi yang dpat diakses dengan mudah mengenai laporan keuangan yang disusun dnegan baik sebenarnya memiliki artian untuk mempermudah pengelola PAUD yang berjumlah 5 orang dan dikepalai oleh Bu Yenni dan 4 staff pendidik mengenai penerimaan dana dan pengeluaran kas selama periode tertentu. Selain tujuan tersebut informasi penerimaan dan pengeluaran kas selama periode tertentu sangat penting untuk memenuhi kebutuhan sebagai berikut :

1. Untuk melakukan perkiraan arus kas di masa yang akan datang, dimana hal ini terkait sumber-sumber penggunaan kas perusahaan atau usaha tidaklah memiliki perubahan secara signifikan dari tahun ke tahun, sehingga penerimaan dan pengeluaran kas akan dapat digunakan sebagai alat untuk memperkirakan penerimaan serta pengeluaran kas dimasa yang akan datang.

2. Melakukan evaluasi dalam pengambilan keputusan manajemen, dimana laporan arus kas ini adalah untuk melaporkan kegiatan investasi perusahaan.

3. Terkait penentuan pemberian atau pembagian hasil bagi usaha (dividen).

4. Pelaporan arus kas yang baik akan membantu investor dan kreditor untuk mengetahui bagaimana perusahaan mampu melakukan pembayaran.

5. Laba bersih juga dapat dilihat dari hasil pelaporan keuangan.

6. Pendeteksi dini kebangkrutan suatu perusahaan atau unit bisnis.

Proses penyuluhan, pelatihan dan pendampingan dalam program pengabdian pada masyarakat ini memerlukan alat dan bahan sebagai berikut :

1. Perangkat multimedia (Komputer/ laptop dan LCD Proyektor).

2. Materi sebagai bahan FGD yang berebntuk Power Point.

3. Materi akuntansi dalam penentuan dan penyusunan laporan keuangan arus kas serta pelaporan akuntansi.

\section{HASIL DAN PEMBAHASAN}

Awal berdirinya PAUD Cita Sakinah merupakan hasil dari musyawarah yang dilakukan oleh para pengelola masjid KH. Ahmad Dahlan. Pada awal berdirinya PAUD ini hanya memiliki 10 orang siswa didik dan 3 guru, seriring berjalannya usia PAUD yang sekarang genap 1 tahun maka diiringi juga dengan peningkatan jumlah siswa didik yaitu berjumlah 25 orang dan terdapat 5 pengelola, 4 diantaranya adalah guru dan 1 berperan sebagai kepa sekolah dari PAUD Cita Sakinah. Pada mulanya Masjid KH Ahmad Dahlan yang dikelola oleh pengurus Muhammadiyah dan memiliki dana infaq kemudian digunakan untuk santunan terhadap masyarakat sekitar yang membutuhkan. Kegiatan pada masjid awalnya dititik beratkan kepada pemberian bantuan kepada masyarakat yang rutin dilakukan adalah kegiatan santunan orang meninggal. Dalam kegiatan ini penggurus masjid memberikan bantuan pembiayaan pemakaman yaitu proses penggalian tanah kubur, dan hal ini 
dilakukan dan terbuka untuk masyarakat umum, dimana masyarakat umum yang dimaksud adalah masyarakat yang berada dalam lingkungan masjid.

Manajemen dari AUM masih bersatu dengan manajemen Masjid terkadang menyulitkan bagi pengelola dalam mengatur keuangan dan Menyusun laporan keuangan mereka. PAUD Cita Sakinah ini berada persis disamping masjid menghadap area parkiran. PAUD Cita Sakinah telah mengalami dua kali pergantian kepala sekolah, ketika saya temui kemarin yang memegang peranan sebagai kepala PAUD adalah bunda ifa begitu anak-anak memanggil beliau. Ada lima pendidik didalam PAUD Cita Sakinah diluar ibu kepala sekolah. Pengasuh di PAUD juga dipanggil dengan bunda, dan pengasuh tersebut sengaja dicari dan diberikan kepada warga masyarakat sekitar AUM, karena tujuan utama dari AUM adalah memberikan kebermanfaatan bagi warga masyarakat sekitar. Dari awal berdirinya PAUD langsung diminati oleh berbagai kalangan, PAUD ini terbuka untuk umum tidak hanya untuk warga persyarikatan muhammadiyah, hal ini terbukti dari adanya anak yang ditipkan dan disekolahkan di PAUD ini dari keluarga NU, bahkan lainnya.

Dengan semakin maju dan berkembangnya PAUD Cita Sakinah maka akan selaras dengan posisi keuangan yang terdapat pada PAUD Cita Sakinah yang juga semakin berkembang. Agar kondisi keuangan PAUD Cita Sakinah dapat berjalan dengan baik secara administratif, maka kami melakukan pengabdian berupa pendampingan pembuatan dan pengelolaan laporan keuangan PAUD Cita Sakinah. Kegiatan pendampingan pembuatan dan pengelolaan ini diikuti oleh seluruh pengurus PAUD Cita Sakinah terutama pengurus inti yang memiliki tugas dan tanggung jawab terhadap kegiatan adminstratif dan keuangan di PAUD tersebut. Dalam pendampingan ini kami membuatkan aplikasi laporan yang terintegrasi dengan komputer dimana pengoperasiannya dibuat dengan user friendly tetapi dengan tingkat komplektifitas laporan keuangan yang lengkap. kegiatan ini berlangsung kurang lebih empat kali kegiatan.

Tahapan pertama, dalam program pendampingan ini yang dilakukan adalah melakukan beberapa observasi dasar mengenai kebutuhan dasar tentang kebutuhan apa saja yang dibutuhkan dalam pembuatan dan penyusunan laporan keuangan apa saja dibutuhkan oleh PAUD Cita Sakinah, karena tujuan dari kegiatan ini adalah berusaha untuk menentukan permasalahan - permasalahan mendasar terkait pengelolaan keuangan pada PAUD Cita Sakinah. Kondisi keuangan suatu perusahaan akan dapat diketahui dari laporan keuangan perusahaan yang bersangkutan, yang terdiri dari neraca, laporan laba rugi serta laporan keuangan lainnya (Riswan \& Kesuma, 2014), (Anas, 2019). Dari hasil observasi dilapangan ditemukan bahwa PAUD Cita Sakinah masih menggunakan pembukuan manual dimana sistem pencatatan yang digunakan masih belum bisa runtut dan sistemik. Permasalahan ini yang menjadikan landasan awal mengapa pengabdian ini sangat penting dilakukan pada PAUD Cita Sakinah.
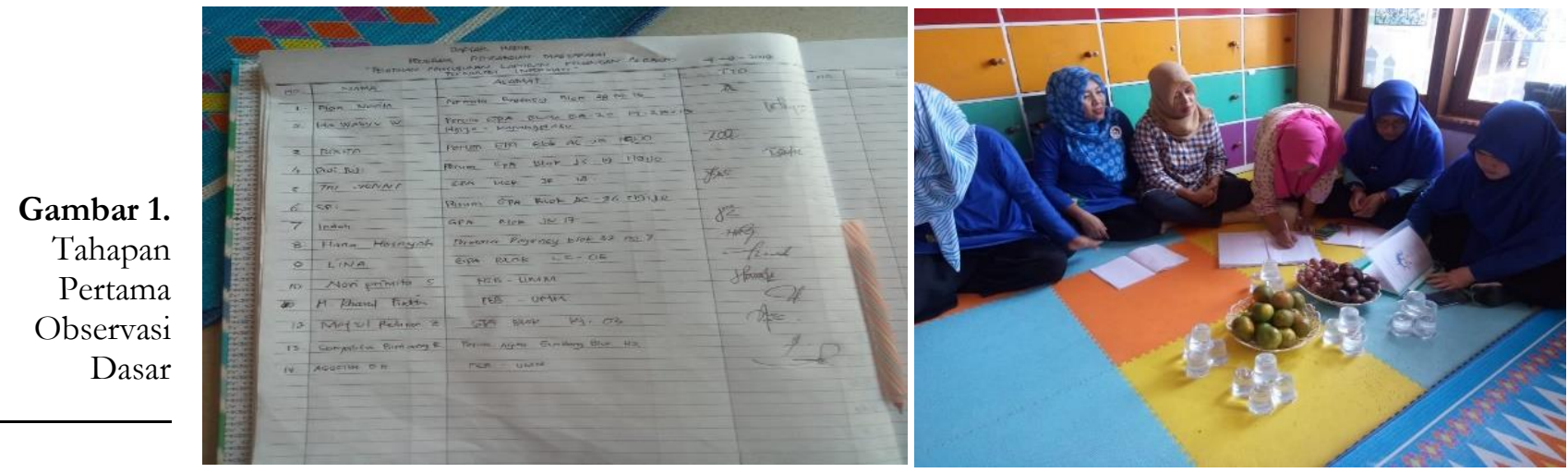

Janayu 1.2 

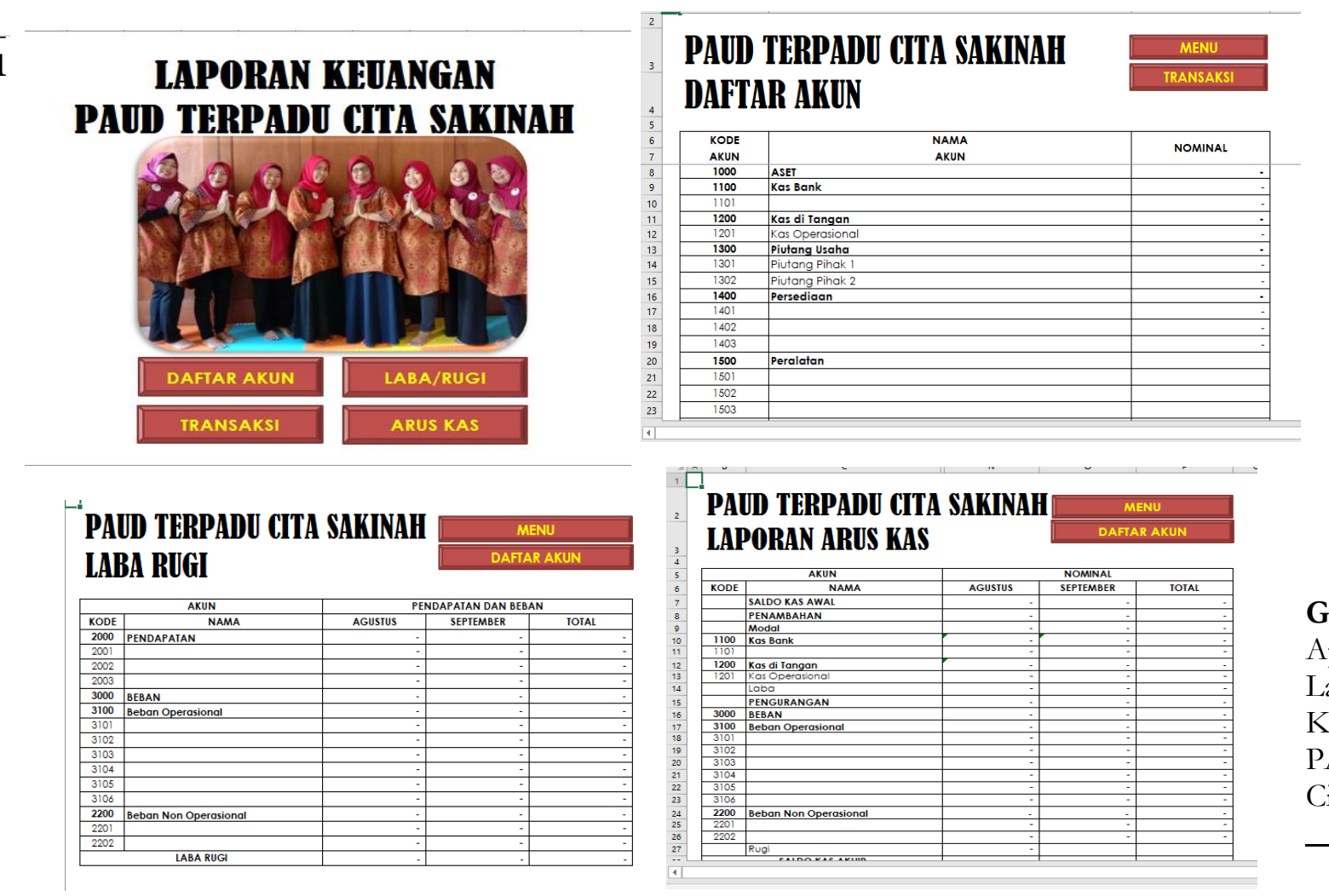

Gambar 2.

Aplikasi

Laporan

Keuangan

PAUD Terpadu

Cita Sakinah

Tahapan kedua, membuat software aplikasi keuangan sederhana tapi cukup powerfull dan kompleks yang memenuhi unsur - unsur pelaporan keuangan menurut standart akuntansi. Berdasarkan SAK ETAP (Standar Akuntansi Keuangan Entitas Tanpa Akuntabilitas Publik) yang dikeluarkan oleh Ikatan Akuntansi Indonesia, setiap perusahaan telah diwajibkan untuk membuat laporan keuangan yang terdiri dari neraca, laporan laba rugi, laporan perubahan modal dan laporan arus kas (Norkamsiah et al., 2016), (Siti \& Heru, 2019), (Tatik, 2018). Tentu saja dalam proses pemuatan software aplikasi keuangan ini disesuaikan dengan kemampuan pengguna yaitu pengurus TPA Cita Sakinah, dimana aplikasi yang dibuat dengan user friendly.

Tahapan ketiga, tahapan ketiga ini, kami selaku tim pengabdian melakukan FGD dengan semua pengurus PAUD Cita Sakinah untuk memperkenalkan progam sofware keuangan beserta mengadakan pendampingan mengenai bagaimana cara operasional software tersebut hingga semua pengurus paham mengenai penggunaan sofware tersebut. Dalam kegiatan ini semua pengurus PAUD Cita akan di laukan pendampingan satu persatu secara komprehensif agar mampu menoperasaikan progam secara maksimal. Tujuan tim pengabdian melakukan training satu persatu terhadap masing - masing pengurus bertujuan agar nantinya pengoperasian aplikasi software keuangan ini tidak hanya dikuasai oleh satu person saja akan tetapi semua pengurus juga bisa mengaplikasikan dan tentunya memahami software laporan keuangan yang sudah dibuat.

Dalam suatu bisnis yang bergerak dengan aktivitas yang dimulai melalui perencanaan bisnis adalah dengan cara melakukan serangkaian bagaimana proses operasi usaha agar mampu mencapai tujuan ternetu dalam hal ini keberlangsungan PAUD Cita Sakinah. Bisnis atau

1.2 suaha yang baik dapat dilihat salah satunya adalah pelaporan keuangannya yang baik dan sistematis. Pelaporan keuangan merupakan sesuatu bentuk tanggung jawab manajemen dalam mengelola sumber daya yang diperoleh selama periode waktu tertentu. 
Pelaporan keuangan yang baik akan memberikan nformasi yang bermanfaat bagi investor untuk melakukan keputusan investasi (Harventy et al., 2020). Pelaporan keuangan arus kas ini mulai diwajibkan pelaporannya di Indonesia pada tahun 1994 dengan ditandainya melalui pernyataan standar akutansi keuangan (PSAK) No 2 yang menyatakan perusahaan harus menyusun laporan arus kas dan menyajikan laporan tersebut sebagai bagian yang tidak terpisahkan dalam pertanggungjawaban (Mansaleo et al., 2016), (Akhsanul Haq, 2015).

\section{Gambar 3.}

FGD

Pendampingan

Penggunaan

Software

Aplikasi

Keuangan

\section{Gambar 4.}

Praktik

Pendampingan

Penggunaan

Software

Aplikasi

Keuangan
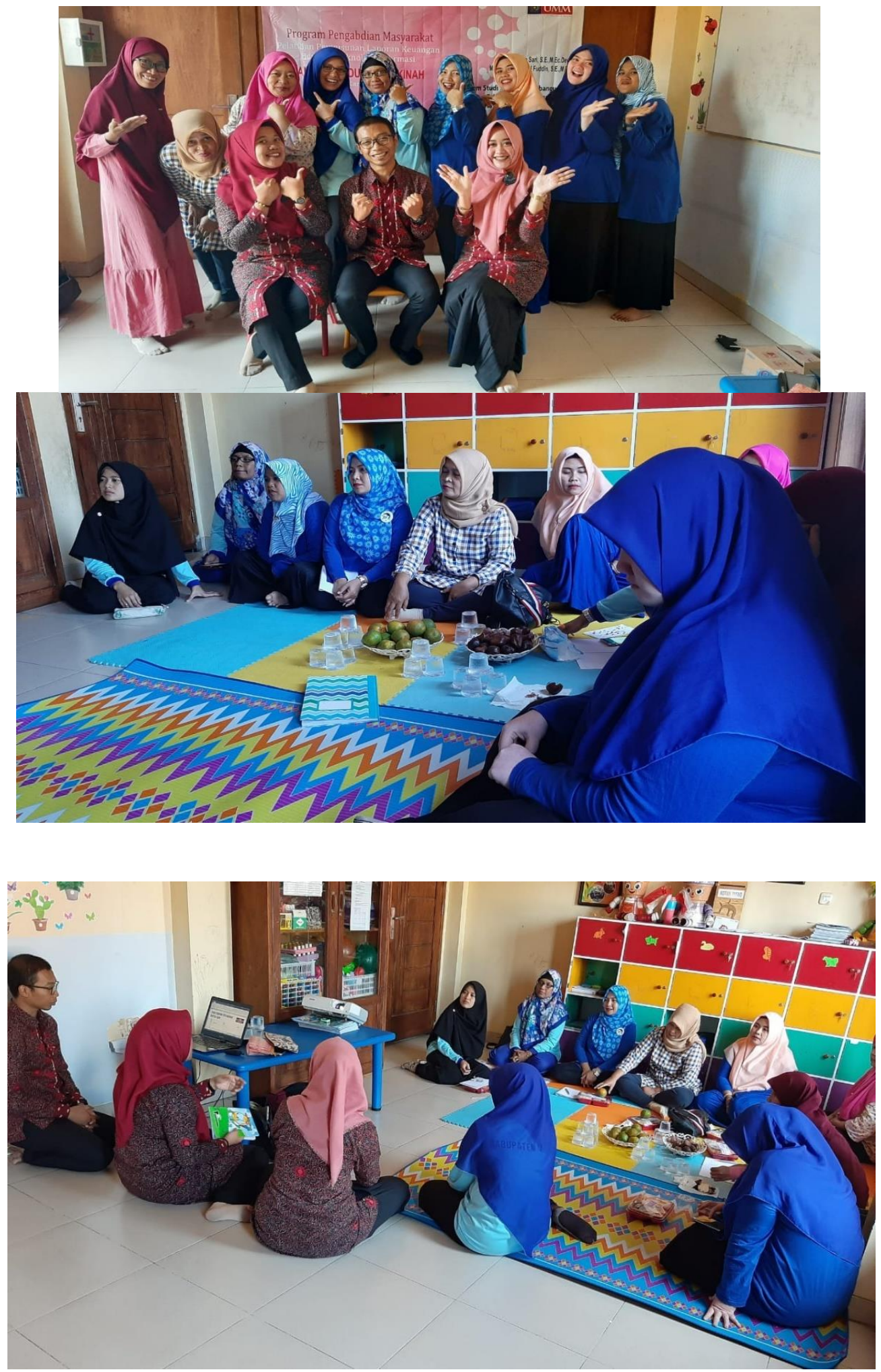

132

\section{Janayu}

\section{2}


Kegiatan pengabdian pada PAUD Cita Sakinah ini dilakukan dalam 4 tahapan, dengan susunan acara pelatihan dan FGD sebagai berikut:

\begin{tabular}{|c|c|c|c|}
\hline No & Hari, Tanggal & Materi & Waktu \\
\hline 1 & Senin, 17 Mei 2019 & $\begin{array}{l}\text { Melakukan beberapa observasi dasar } \\
\text { mengenai kebutuhan dasar tentang } \\
\text { kebutuhan apa saja yang dibutuhkan } \\
\text { dalam pembuatan dan penyusunan } \\
\text { laporan keuangan apa saja } \\
\text { dibutuhkan oleh PAUD Cita } \\
\text { Sakinah }\end{array}$ & $09.00-12.00$ \\
\hline 2 & Kamis, 18 Juli 2019 & $\begin{array}{l}\text { Tim membuat software aplikasi } \\
\text { keuangan sederhana tapi cukup } \\
\text { powerfull dan kompleks yang } \\
\text { memenuhi unsur - unsur pelaporan } \\
\text { keuangan menurut standart } \\
\text { akuntansi }\end{array}$ & - \\
\hline \multirow[t]{3}{*}{3} & $\begin{array}{l}\text { Selasa, } 13 \text { Agustus } \\
2019\end{array}$ & $\begin{array}{l}\text { tim pengabdian melakukan FGD } \\
\text { dengan semua pengurus PAUD Cita } \\
\text { Sakinah untuk memperkenalkan } \\
\text { progam sofware keuangan beserta } \\
\text { mengadakan pendampingan } \\
\text { mengenai bagaimana cara } \\
\text { operasional software }\end{array}$ & $09.00-11.30$ \\
\hline & & ISHOMA & $11.30-13.00$ \\
\hline & & FGD Sesi II & $13.00-15.00$ \\
\hline 4 & $\begin{array}{l}\text { Rabu, } 4 \text { September } \\
2019\end{array}$ & $\begin{array}{l}\text { Monitoring dan Evaluasi pada } \\
\text { PAUD Cita Sakinah secara berkala }\end{array}$ & - \\
\hline
\end{tabular}

Tabel 1.

Tabel Susunan Acara Pelatihan dan FGD

Tahapan keempat yang dilakukan adalah secara berkala tim pengabdian akan berusaha melakukan pengecekan terkait progam keuangan yang telah digunakan oleh PAUD Cita Sakinah terkait dengan apakah ada kendala dalam pengoprasian aplikasi yang telah dibuatkan oleh tim pengabdian dan nantinya apakah ada kemungkinan untuk dilakukan upgrade software terhadap laporan keuangan PAUD Cita Sakinah. Dalam waktu jangka panjang harapan selanjutnya yang diingimkan bersama adalah ketika PAUD Cita Sakinah sudah mampu mengatur kondisi keuangannya, tim pengabdian juga akan berusaha membuatkan pelatihan dan pendampingan mengenai laporan keuangan yang sesuai dengan standart akuntansi di usaha turunan yang dimiliki oleh PAUD Cita Sakinah atau amal usaha muhammadiyah lain yang berada dalam lingkungan yang sama

Kegiatan pengabdian pelaporan keuangan yang telah dilaksanakan pada PAUD Cita Sakinah ini sangat menunjukkan antusiasme yang sangat tinggi dari para pengurus PAUD. Antusiasme ini ditunjukkan melalui banyaknya pertanyaan yang dilontarkan oleh peserta mengenai bagaimana penyusunan pelaporan keuangan yang digunakan menggunakan aplikasi yang telah tim buat sebelumnya. Saat dilakukan kegiatan monitoring dan evaluasi terhadap PAUD mengenai pelaporan keuangan yang dilakukan setelah beberapa saat yang

1.2 disusun oleh tim pengurus PAUD Cita Sakinah, terlihat bahwa pengelola atau pengurus masih belum cakap dalam membaca laporan yang telah dibuat sendiri, sehingga tim 
pelaksana pengabbdian memberikan penjelasan bagaimana penyusunan laporan arus kas kembali.

\section{SIMPULAN}

Pengabdian yang dilakukan di TPA Cita Sakinah ini bertujuan untuk melakukan pendampingan pengelolaan keuangan melalui pembuatan software keuangan yang sesuai dengan standart akuntansi. Pemberian pendampingan penyusunan laporan keuangan ini sangat bermanfaat dan dirasakan sangat besar manfaatnya bagi mitra dalam hal ini adalah PAUD Cita Sakinah, karena adanya manajemen keuangan yang masih menjadi satu dengan amal usaha lain sehingga terkadang terjadi kerancuan, kurangnya kemampuan para pengelola AUM PAUD Cita Sakinah dalam pengelolaan keuangan karena masih menggunakan perhitungan manual dan sangat sederhana. Selama proses pendampingan tidak ada hambatan sehingga kegiatan dapat dilaksanakan dengan lancer, semua peserta undangan hadir tepat waktu dan mereka yang hadir memang rata-rata tidak terlalu mahir dan cakap dalam melakukan operasi menggunakan computer apalagi menggunakan software keuangan yang telah tim kami susun. Sehingga dengan keadaan tersebut tim pednampingan terus melakukan koordinasi dengan bagian-bagian yang menangani laporan keuangan secara langsung pada PAUD Cita Sakinah.

Pada proses pendampingan ini dihadiri langsung oleh pengurus TPA Cita Sakinah dengan tim pengabdian dimana pertemuan dibagi menjadi lima sesi, yaitu diskusi awal mengenai kebutuhan dasar aplikasi keuangan TPA Cita Sakinah, kedua pembuatan software, ketiga demo sekaligus sosialisasi penggunaan software dan yang keempat adalah maintenence yang dilakukan oleh tim pengabdian secara berkala terhadap progam yang telah dibuat untuk TPA Cita Sakinah. Karena berdirinya PAUD Cita Sakinah masih tergolong masih baru sehingga kepengurusan masih belum terakomodir dengan jelas mengingat masih menjadi satu dengan tiga aum yang lain, sehingga perlu dipetakan benar-benar bagi sumber daya yang memang diharuskan mengelola keuangan PAUD.

\section{DAFTAR PUSTAKA}

Akhsanul Haq, H. C. (2015). Pengaruh Penerapan PSAK 2 (Laporan Arus Kas) Terhadap Indikator Keputusan Investasi Pada PT Goodyear Tbk Tahun 2009 - 2013. Jurnal Ilmiah Akuntansi Fakultas Ekonomi, 1(Tahun), 10-14.

Anas, A. (2019). Implementasi Peraturan Menteri Keuangan No. 76 TAHUN 2008 Tentang Pedoman Akuntansi Dan Pelaporan Keuangan Badan Layanan Umum Di Pusat Bisnis UIN Sunan Ampel Surabaya. AKUNTANSI: Jurnal Akuntansi Integratif, 02(01), 1-12.

Harventy, G., Zubaidah, S., \& Kholmi, M. (2020). Pendampingan Penyusunan Pelaporan Keuangan Pada Kelompok Usaha Kecil Dan Menengah Brosem Semeru. Jurnal Pengabdian Dan Peningkatan Mutu Masyarakat (Janayu), 1(1), 60-74. https://doi.org/10.22219/janayu.v1i1.11174

Mansaleo, R. P., Manossoh, H., \& Tirayoh, V. Z. (2016). Evaluasi Penerapan Laporan Arus Kas Perbankan Yang Terdaftar Di Bursa Efek Indonesia (BEI) Banking Companies Listed In Indonesia Stock Exchange (IDX). Jurnal Berkala Ilmiah Efisiensi, 16(04), 962970.

Norkamsiah, Agus, I. K., \& Agus, S. (2016). Penerapan Standar Akuntansi Keuangan Entitas Tanpa Akuntabilitas Publik (SAK ETAP) Pada Penyusunan Laporan

Janayu 1.2 Keuangan. AKUNTABEL: Jurnal Ekonomi Dan Keuangan, 13(2), 151-163. 
Nurmila, R. F. (2017). Analisis Perhatian Wanita Karir Terhadap Keberhasilan Pendidikan Anak Dalam Keluarga Di Dusun Sawagi Kecamatan Pattallassang Kabupaten Gowa. Jurnal Pendidikan Teknologi Pertanian, 3(9), 223-227. https://doi.org/10.1017/CBO9781107415324.004

Purnomo, H. (2013). Peran Orang Tua dalam Optimalisasi Tumbuh Kembang Anak untuk Membangun Karakter Anak Usia Dini. Prosiding Seminar Nasional Parenting, 34-47.

Rahmayuni, S. (2017). Peranan Laporan Keuangan dalam Menunjang Peningkatan Pendapatan Pada UKM. JSHP (Jumal Sosial Humaniora Dan Pendidikan), 1(1), 93. https://doi.org/10.32487/jshp.v1i1.239

Riswan, \& Kesuma, Y. F. (2014). Analisis Laporan Keuangan Sebagai Dasar Dalam Penilaian Kinerja Keuangan Pt. Budi Satria Wahana Motor. Jurnal Akuntansi \& Keuangan, 5(1), 93-121.

Siti, R. N., \& Heru, F. (2019). Analisis Penerapan Pelaporan Keuangan Entitas Nirlaba Berdasarkan PSAK NO. 45 Pada Masjid Di Kota Banda. Jurnal Ilmiah Mahasiswa Ekonomi Akuntansi (JIMEKA), 4(2), 374-382.

Tatik. (2018). Implementasi SAK EMKM ( Standar Akuntansi Keuangan Entitas Mikro Kecil Dan Menengah ) Pada Laporan Keuangan UMKM (Studi Kasus Pada UMKM XYZ Yogyakarta). Jurnal Relasi, XIV(02), 1-14. 